\title{
Welcoming articles on genotype-dependent clinical features and diagnostics
}

\author{
Georg Auburger ${ }^{1}$ - Manuel B. Graeber ${ }^{2}$ - Louis J. Ptáček ${ }^{3}$
}

Published online: 1 April 2021

(C) The Author(s) 2021

The rapid expansion of molecular genetics was catalyzed in 1949 by the first identification of an "allelic change in a single gene", the E6V substitution in hemoglobin that is responsible for sickle cell anemia [1]. It was a surprise for many researchers then, that this disorder which is characterized by many crises of pain due to vaso-occlusion in fingers, chest, spleen or penis, by aplastic or hemolytic crises, and by stroke episodes, should be due to a constitutively present mutation. Decades later, neurogenetic research documented many variants of epilepsy and episodic ataxia, dyskinesia and paralysis to be caused by constitutive mutations in ion channels or other synaptic machinery [2]. It was also surprising that the hemoglobin aggregation underlying the sickle cell trait appears only in venous blood and readily disappears in reoxygenated arterial blood [3]. Again, neurogenetic research decades later showed how mutation-triggered protein aggregates that underlie age-associated neurodegeneration and dementia appear preferentially in neurons when glutamate/calcium-dependent environmental conditions are propitious [4]. These are examples that illustrate how the identification of causal mutations made it possible to experimentally unravel disease mechanisms, and thus to explain the associated clinical phenotypes, overall improving patient diagnostics and preventive treatment. Since its foundation in 1997, the journal

Georg Auburger

auburger@em.uni-frankfurt.de

1 Experimental Neurology, Medical Faculty, Goethe University, 60590 Frankfurt, Germany

2 Brain and Mind Centre, University of Sydney, 94 Mallet St, Camperdown, NSW 2050, Australia

3 Department of Neurology, University of California, San Francisco, USA
Neurogenetics is committed to facilitating such research into rare genetic disorders of the nervous system.

In the past, exome sequencing of single cases has often left causality in doubt until in vitro experiments added the necessary evidence or animal models were generated that recapitulated the phenotype. Similarly, association studies of complex multifactorial conditions often led to spurious significance, which could not be confirmed. It is one of our task as editors to help weed out such inconclusive results.

In recent years, a sufficient number of cases even of rare clinical entities have become known to allow confident conclusions about their respective phenotype spectrum, their prodromal features and common treatment complications; enough mutations are known to understand the aberrant activity or interactions of each disease protein; enough disease genes are known to evaluate the pathogenetic pathways of a syndrome; enough expression profiles from peripheral tissues are documented to establish diagnostic criteria; therefore, we encourage authors to not only report some novel findings in a few of their patients, but also to embark on their comparison and comprehensive analysis. It is also desirable to go beyond DNA studies, either establishing additional diagnostic signatures, or analyzing pathogenesis and disease rescue in model systems.

With these goals in mind, we welcome the insights gained from recent Neurogenetics articles on expanded phenotypes in spastic paraplegia [5], on prodromal cognitive symptoms in SCA48 [6], on neuroimaging correlates of MYORG mutations [7] and of C1R mutations [8], on the oxidative stress triggered by PTCD3 mutations [9], on cell morphology analyses in ARSACS patient cells [10], on the interaction with transcription factors of CtBP1 [11], and on expression profiles modulated by the NDRG family [12].

We strongly invite submission of more such articles. Many thrilling developments continue to happen in our field, and we are eager to further expand the scope of Neurogenetics especially in the clinical arena in the coming years. 
Funding Open Access funding enabled and organized by Projekt DEAL.

Open Access This article is licensed under a Creative Commons Attribution 4.0 International License, which permits use, sharing, adaptation, distribution and reproduction in any medium or format, as long as you give appropriate credit to the original author(s) and the source, provide a link to the Creative Commons licence, and indicate if changes were made. The images or other third party material in this article are included in the article's Creative Commons licence, unless indicated otherwise in a credit line to the material. If material is not included in the article's Creative Commons licence and your intended use is not permitted by statutory regulation or exceeds the permitted use, you will need to obtain permission directly from the copyright holder. To view a copy of this licence, visit http://creativecommons.org/licenses/by/4.0/.

\section{References}

1. Pauling L; Itano HA; Singer SJ; Wells IC (1949-11-01). "Sickle Cell Anemia, a Molecular Disease”. Science. 110 (2865): 543-548. PMID 15395398

2. Ptáček LJ (2015) Episodic disorders: channelopathies and beyond. Annu Rev. Physiol. 77:475-479

3. Strasser BJ (1999-11-19). "Perspectives: Molecular Medicine: "Sickle Cell Anemia, a Molecular Disease“““. Science. 286 (5444): 1488-1490. PMID 10610548

4. Koch P, Breuer P, Peitz M, Jungverdorben J, Kesavan J, Poppe D, Doerr J, Ladewig J, Mertens J, Tüting T, Hoffmann P, Klockgether T, Evert BO, Wüllner U, Brüstle O et al (2011 Nov 23) Nature. 480(7378):543-546

5. Elert-Dobkowska E, Stepniak I, Krysa W, Ziora-Jakutowicz K, Rakowicz M, Sobanska A, Pilch J, Antczak-Marach D, Zaremba J, Sulek A (2019 Mar) Next-generation sequencing study reveals the broader variant spectrum of hereditary spastic paraplegia and related phenotypes. Neurogen. 20(1):27-38
6. Palvadeau R, Kaya-Güleç ZE, Șimşir G, Vural A, Öztop-Çakmak Ö, Genç G, Aygün MS, Falay O, Başak AN, Ertan S (2020 Jan) Cerebellar cognitive-affective syndrome preceding ataxia associated with complex extrapyramidal features in a Turkish SCA48 family. Neurogen. 21(1):51-58

7. Ramos EM, Roca A, Chumchim N, Dokuru DR, Van Berlo V, De Michele G, Lieto M, Tedeschi E, De Michele G, Coppola G (2019 May) Primary familial brain calcification caused by a novel homozygous MYORG mutation in a consanguineous Italian family. Neurogen. 20(2):99-102

8. Kapferer-Seebacher I, Waisfisz Q, Boesch S, Bronk M, van Tintelen P, Gizewski ER, Groebner R, Zschocke J, van der Knaap MS (2019 Mar) Periodontal Ehlers-Danlos syndrome is associated with leukoencephalopathy. Neurogen. 20(1):1-8

9. Borna NN, Kishita Y, Kohda M, Lim SC, Shimura M, Wu Y, Mogushi K, Yatsuka Y, Harashima H, Hisatomi Y, Fushimi T, Ichimoto K, Murayama K, Ohtake A, Okazaki Y (2019 Mar) Mitochondrial ribosomal protein PTCD3 mutations cause oxidative phosphorylation defects with Leigh syndrome. Neurogen. 20(1):925

10. Ricca I, Morani F, Bacci GM, Nesti C, Caputo R, Tessa A, Santorelli FM (2019 Mar) Clinical and molecular studies in two new cases of ARSACS. Neurogen. 20(1):45-49

11. Beck DB, Subramanian T, Vijayalingam S, Ezekiel UR, Donkervoort S, Yang ML, Dubbs HA, Ortiz-Gonzalez XR, Lakhani S, Segal D, Au M, Graham JM Jr, Verma S, Waggoner D, Shinawi M, Bönnemann CG, Chung WK, Chinnadurai G (2019 Aug) A pathogenic CtBP1 missense mutation causes altered cofactor binding and transcriptional activity. Neurogen. 20(3):129-143

12. Schonkeren SL, Massen M, van der Horst R, Koch A, Vaes N, Melotte V, Nervous NDRG (2019 Oct) the N-myc downstreamregulated gene family in the central and peripheral nervous system. Neurogen. 20(4):173-186

Publisher's note Springer Nature remains neutral with regard to jurisdictional claims in published maps and institutional affiliations. 